\title{
PENGARUH KETERAMPILAN SOSIAL TERHADAP HASIL BELAJAR SISWA BERKEBUTUHAN KHUSUS DI SDN 2 WRINGINANOM KAB. GRESIK
}

\author{
Afifah \\ STAI Taruna Surabaya \\ Email : Afifahsyahira48@gmail.com
}

\begin{abstract}
Every citizen has the same right to obtain quality education. Even citizens who have physical, emotional, mental, intellectual or social disabilities are also entitled to education even though they have to go through special education. With the existence of this study aims to determine the social skills of students with special needs in SDN 2 WringinomKab. Gresik, to find out the learning outcomes of students with special needs at SDN 2 WringinomKab. Gresik, and to find out how the influence of social skills on the learning outcomes of students with special needs at SDN 2 WringinomKab. Gresik The type used in this research is quantitative research, in this case the researcher uses independent correlation to look for relationships and test hypotheses between two or more variables. The object of asdalah research at SDN 2 Wringinom district. Gresik, researchers used product moment correlation techniques. The data collection techniques the methods that researchers use are observation, questionnaire and documentation, while for data analysis techniques using descriptive analysis and Inferential analysis. Hopefully with this research the teacher should increase student confidence (self-efficacy) so that students with special needs feel confident in their potential and are able to complete their learning tasks as well as possible, and further researchers should conduct research on other aspects because there are many other aspects / factors that affect ABK student learning outcomes.
\end{abstract}

Keywords: Social Skills, Students with Special Needs

\section{Pendahuluan}

Pendidikan merupakan suatu kebutuhan yang sangat penting, setiap manusia pasti membutuhkan pendidikan agar bisa memperoleh pengetahuan dan wawasan yang lebih luas serta bisa menjadi orang yang bermanfaat untuk orang lain. Jika pendidikan bermutu maka akan menghasilkan (SDM) yang bermutu pula. Oleh karena itu negara ini memberikan kewajiban untuk memberikan kesempatan kepada warganya untuk memperoleh hak pendidikan tanpa terkecuali tanpa membedakan antara satu dengan yang lainnya. Undang-undang dasar 1945 pada pasal 31 ayat 1 dan undang-undang Nomor 20 tahun 2003 tentang sistem pendidikan nasional bahwa setiap warga negara mempunyai hak yang sama untuk memperoleh pendidikan yang bermutu. Bahkan warga negara yang mempunyai kelainan fisik, emosional, mental intelektual atau sosial pun berhak mendapatkan pendidikan 
walaupun harus melalui pendidikan yang khusus. Hambatan kelainan atau memiliki kemampuan potensi kecerdasan dan bakat istimewa berhak pula mendapatkan kesempatan yang sama dengan anak lainnya (anak normal) dalam layanan pendidikan $^{1}$.

Jaminan pendidikan bagi semua kalangan tanpa terkecuali telah menjadi komitmen bersama negara-negara di dunia untuk memperjuangkan hak dasar anak dalam memperoleh pendidikan. Deklarasi dunia Jomtien merupakan salah satu upaya berskala internasional guna mendorong dan memastikan semua anak memperoleh pendidikan tanpa memandang latar belakang dan ketidaknormalan bagi segi fisik maupun mental. Untuk itulah paradigma pendidikan inklusif dikembangkan dan dipraktikkan di berbagai negara termasuk Indonesia. Dengan ini bahwa pendidikan untuk peserta didik yang berkebutuhan khusus mempunyai hak dan perlindungan yang jelas yang sudah tertera dalam UUD 1945 untuk mendapatkan pendidikan yang layak serta memadai dan tidak membeda-bedakan peserta didik yang normal maupun abnormal.

Peserta didik berkebutuhan khusus merupakan label yang ditujukan bagi seorang peserta didik yang memerlukan bantuan sesuai dengan kemampuan maupun hambatan yang dimilikinya dengan tujuan untuk mengembangkan potensi yang dimilikinya. Anak berkebutuhan khusus adalah mereka yang karena suatu hal khusus membutuhkan pelayanan pendidikan khusus, agar potensinya dapat berkembang secara optimal. Mengingat bahwa pentingnya pendidikan untuk semua orang juga anak-anak termasuk juga pada kelompok difabel, maka kemudian muncul konsep pendidikan inklusif. Paradigma pendidikan inklusif menjadi solusi untuk melanjutkan pendidikan tanpa harus merasa kecil hati ketika harus berkumpul dengan mereka yang memiliki fisik normal.

Dinamika dan masalah keterampilan sosial pada setting sekolah menjadi persoalan yang menarik untuk dikaji, terutama pada sekolah yang memiliki siswa dengan latar belakang yang beragam, keberagaman anak kerap ditemui di sekolah ${ }^{2}$. Idealnya ketika anak berada di sekolah, mereka akan mendapatkan dan menunjukkan perkembangan yang tidak diperoleh dari lingkungan keluarga seperti misalnya bersosialisasi dengan teman, guru, dan aktivitas lain dengan lingkungan di

\footnotetext{
${ }^{1}$ Presiden RI. Undang-Undang Republik Indonesia, (Jakarta: Repubik Indonesia, 2013). Hal. 20

${ }^{2}$ Tin Suharmin dkk,"Pengembangan Pengukuran Keterampilan Sosial Siswa SekolahDasar Inklusif Berbasis Diversity Awareness". Jurnal Penelitian Ilmu Pendidikan. Vol 1. 2017. Hal. 01
} 
sekolah. Keterampilan sosial peserta didik di sekolah inklusif seringkali menjadi persoalan sekaligus menjadi tantangan untuk disikapi secara positif. Problem keterampilan sosial yang dialami peserta didik di sekolah inklusif tampak pada berbagai perilaku dalam pembelajaran maupun non pembelajaran. Sekolah inklusif pada umumnya telah melakukan upaya untuk mengatasi rendahnya keterampilan sosial peserta didiknya ${ }^{3}$, sehingga dari upaya ini diharapkan setiap peserta didik tidak ada yang merasa minder untuk memperoleh pendidikan, mereka merasa dihargai dan diperhatikan, maka dari rasa ini lah secara tidak langsung sekolah maupun pihak-pihak yang terkait (bapak/ibu pendidik) memunculkan motivasi dari diri mereka untuk menempuh pendidikan dengan rasa penuh semangat.

Selain itu pemerintah kemudian menyediakan layanan pendidikan inklusif yang pelaksanaanya diamanatkan kepada pemerintah. Yaitu dengan hadirnya pendidikan inklusif, keberagaman yang ada di sekolah inklusif menjadi tantangan tersendiri bagi pengembangan keterampilan sosial peserta didik. Bagi peserta didik dengan kebutuhan khusus, sekolah dapat menjadi tempat yang baik untuk mengembangkan kemampuan komunikasi, adaptasi, kepercayaan diri, keterlibatan sosial, berteman, dan mengatasi masalah. Layanan terhadap keberagaman anak merupakan cerminan kualitas pendidikan, selama ini di sekolah inklusif, pendidik juga semakin menyadari bahwa layanan ditujukan ke semua anak, tidak terbatas pada anak berkebutuhan khusus. Menurut Kluth, hal tersebut dalam pernyataannya bahwa pendidikan yang berkualitas dapat tercermin dari pemberian program yang menjangkau semua anak supaya mereka dapat berkembang secara intelektual dan sosial secara maksimal, dan bukan pemberian program yang sama untuk semua anak.

Hal tersebut selaras dengan pendapat diatas bahwa dengan hadirnya pendidikan inklusif tidak ada diskriminasi terhadap peserta didik yang tergolong ke dalam anak berkebutuhan khusus. Anak yang autis, hiperaktif atau yang berkebutuhan lain, semua dapat terintegrasi kedalam kelas reguler pada setiap jenjang pendidikan, kemampuan peserta didik untuk berinteraksi dan berperilaku yang dapat diterima secara sosial merupakan hal yang penting bagi peserta didik untuk hidup dalam suatu masyarakat. Hal tersebut menunjukkan peserta didik berkebutuhan khusus juga memerlukan interaksi dengan orang lain, seperti dengan

${ }^{3}$ Tin Suharmin dkk,"Pengembangan Pengukuran Keterampilan Sosial Siswa SekolahDasar Inklusif Berbasis Diversity Awarenes........Hal.01 
teman sebaya, keterampilan sosial perlu dikuasai anak karena akan membekali anak untuk memasuki kehidupan sosial yang lebih luas baik di lingkungan rumah terlebih lagi di lingkungan sekolah yang akan segera dimasukinya. Lingkungan pertama tempat anak melatih keterampilan sosialnya selain di lingkungan keluarga adalah lingkungan sekolah, dan pendidik adalah pihak yang cukup berkompeten dalam mengenalkan bagaimana cara berinteraksi dengan lingkungan sekolah.

Adapun aspek afektif yang merupakan hasil dari kegiatan pembelajaran adalah keterampilan sosial, bahwa keterampilan sosial adalah salah satu sikap yang dimiliki peserta didik sebagai hasil dari proses pembelajaran, yaitu memiliki sikap keterampilan sosial. Keterampilan sosial perlu dimiliki peserta didik karena keterampilan sosial dapat mempermudah peserta didik berinteraksi, bersosialisasi dan mempengaruhi keberhasilan dalam pembelajaran.

Penting bagi setiap siswa untuk memiliki relasi yang positif dengan teman sebaya di masa kanak-kanak pertengahan dan akhir. Seperti terlibat dalam interaksi yang positif dengan teman sebaya, menyelesaikan konflik, serta memiliki persahabatan. Relasi positif di sekolah dasar inklusif tidak hanya pada sesama siswa berkebutuhan khusus, melainkan relasi positif dengan semua siswa, baik siswa berkebutuhan khusus maupun siswa reguler. Keterampilan sosial siswa berkebutuhan khusus ketika di sekolah inklusif sosialnya yang lebih baik, lebih sering berinteraksi dengan teman sebaya termasuk siswa reguler, perilaku yang lebih sesuai di kelas ${ }^{4}$. Sekolah inklusif dianggap dapat memberi berbagai manfaat baik masyarakat umum maupun bagi anak berkebutuhan khusus. Masyarakat akan mulai mau menerima keberadaan anak berkebutuhan khusus. Selain itu di sekolah inklusif juga memungkinkan anak berkebutuhan khusus belajar bersama dengan anak normal, dan diperlakukan selayaknya anak normal.

Dari latar belakang di atas, maka peneliti berkeinginan untuk melakukan penelitian, "Pengaruh Keterampilam Sosial Terhadap Hasil Belajar Siswa Berkebutuhan Khusus Di SDN 2 Wringinanom Kab. Gresik”.

\section{Pembahasan}

\section{a. Metode Penelitian}

${ }^{4}$ Rina, Diahwati, dkk. "Keterampilan Sosial siswa Berkebutuhan Khusus diSekolahDasar Inklusi, Jurnal Pendidikan. Vol, 1. 2016. Hal.06 
Metode penelitian pada dasarnya merupakan cara ilmiah untuk mendapatkan data dengan tujuan dan kegunaan tertentu (Sugiyono 2015 : 2). Metode penelitian ini digunakan untuk memahami dan memecahkan masalah pada suatu penelitian. Jenis yang digunakan penelitian ini adalah penelitian kuantitatif, yakni metode penelitian yang berlandaskan pada filsafat positifisme, digunakan untuk meneliti pada populasi atau sampel tertentu, pengumpulan data menggunakan instrumen penelitian, analisis data yang bersifat kuantitatif, dengan tujuan untuk menguji korelasi yang telah ditetapkan. Dalam hal ini peneliti menggunakan pendekatan kuantitatif dan menggunakan korelasi independen dimana korelasi ini digunakan untuk mencari hubungan dan menguji hipotesis antara dua variable atau lebih. Objek penelitian yang digunakan penulis yaitu di SDN 2 Wringinanom kab. Gresik, dalam menentukan sampel penelitian, peneliti menggunakan metode analisis deskriptif. Sampel yang digunakan dalam penelitian ini sebanyak 20 siswa berkebutuhan khusus di SDN 2 Wringinanom Kab. Gresik. Adapun teknik pengumpulan data metode yang peneliti gunakan adalah observasi, kuosioner dan dokumentasi.

\section{b. Data Tentang Keterampilan Sosial Siswa Berkebutuhan Khusus di SDN 2 Wringinanom Kab. Gresik}

Data observasi dalam penelitian ini berupa penyataan tentang ketercapaian indikator ketrampilan sosial siswa pada penelitian ini disajikan dalam bentuk tabel sebagai berikut

Tabel I

Ketercapaian Indikator Ketrampilan Sosial

\begin{tabular}{cccc}
\hline Subjek & Nama & Kelas & Skor \\
\hline 1 & FL & 1 & 13 \\
2 & MK & 2 & 12 \\
3 & NO & 2 & 14 \\
4 & MA & 2 & 10 \\
5 & LM & 2 & 11 \\
6 & NF & 2 & 12 \\
7 & DB & 3 & 12 \\
8 & MR & 3 & 14 \\
9 & ND & 3 & 13 \\
10 & MA & 3 & 13
\end{tabular}


Jurnal Keislaman, Vol. 4, No. 2, September

\begin{tabular}{cccc}
11 & CA & 4 & 12 \\
12 & TF & 4 & 12 \\
13 & MH & 4 & 8 \\
14 & AP & 4 & 12 \\
15 & OA & 4 & 13 \\
16 & BY & 4 & 5 \\
17 & R & 4 & 12 \\
18 & MA & 5 & 11 \\
19 & MR & 5 & 12 \\
20 & GM & 5 & 9 \\
\hline
\end{tabular}

Berdasarkan Tabel di atas dapat diketahui hasil penilaian ketrampilan sosial siswa berdasarkan ketercapaian indikator-indikator ketrampilan sosial. Hasil diperoleh 13 siswa mencapai $\geq 10$ indikator $(\geq 62,5 \%)$ sedangkan 3 siswa hanya mencapai $\leq 9$ indikator $(\leq 56,25 \%)$. Siswa yang mencapai indikator terendah terdapat pada kelas 4 dan 5.Rata-rata ketercapaian indikator klasikal sebesar 11,5.

Hasil ini berarti ketrampilan sosial siswa dalam kategori tinggi. Hasil 13 siswa mencapai $\geq 10$ indikator ini menunjukkan bahwa $81,25 \%$ siswa berkebutuhan khusus di SDN 2 Wringinanom Kab. Gresik telah mencapai indikator ketrampilan sosial.

Ketercapaian indikator dalam setiap aspek ketrampilan sosial siswa pada penelitian ini disajikan dalam bentuk tabel sebagai berikut:

Tabel II

Ketercapaian Indikator dalam Setiap Aspek

\begin{tabular}{ccccc}
\hline No & Aspek & Indikator & Skor & Mean (M) \\
\hline 1 & Kerjasama & 1 & 18 & 12,2 \\
& & 2 & 19 & \\
& & 3 & 5 & \\
& & 4 & 18 & \\
\hline 2 & Asersi & 5 & 1 & 15 \\
& & 6 & 17 & \\
\hline 3 & Tanggung Jawab & 7 & 13 & 17 \\
& & 8 & 15 & \\
\hline 4 & & 10 & 19 & 11,5 \\
& & 11 & 17 & 16
\end{tabular}


Berdasarkan Tabel II dapat diketahui skor rata-rata ketercapaian indikator yaitu ketercapaian tertinggi pada aspek tanggung jawab $(M=17)$ sedangkan ketercapaian terendah pada aspek empati $(M=11,5)$. Urutan ketercapaian indikator berdasarkan aspek ketrampilan sosial dari tertinggi ke terendah sebagai berikut: 1) tanggung jawab, 2) kontrol diri, 3) asersi, 4) kerja sama, 5) empati.

Terdapat 3 indikator yang sangat perlu dilakukan peningkatan yaitu indikator 3 (mengerjakan tugas tepat waktu), indikator 5 (memanfaatkan waktu luang) dan indikator 13 (membicarakan suatu masalah pendapat dengan teman sekelas). Perbedaan ketrampilan sosial siswa antar kelas disajikan dalam tabel sebagai berikut.

Tabel III

Tabel Perbedaan Ketrampilan Sosial antar Kelas

\begin{tabular}{cc}
\hline Kelas & Mean \\
\hline 1 & 13,00 \\
2 & 11,80 \\
3 & 13,00 \\
4 & 10,57 \\
5 & 10,67 \\
\hline
\end{tabular}

Berdasarkan Tabel III dapat diketahui nilai rata-rata ketrampilan sosial siswa antar kelas cenderung sama. Hasil nilai rata-rata yang cenderung menunjukkan tidak adanya perbedaan yang signifikan ketrampilan sosial siswa antar kelas.

\section{c. Data Hasil Belajar Siswa Berkebutuhan Khusus di SDN 2 Wringinanom}

\section{Kab. Gresik}

Ketercapaian hasil belajar siswa secara keseluruhan diperoleh nilai ratarata 79,28 dalam kategori nilai yang tinggi. Hasil ini menunjukkan bahwa siswa berkebutuhan khusus berhasil dalam mempelajari materi yang diajarkan sehingga mengalami perubahan tingkah laku. Hal ini sesuai pendapat Winkel bahwa hasil belajar sebagai perubahan tingkah laku setelah anak melakukan 
kegiatan belajar yang dinyatakan dalam skor yang diperoleh dari hasil tes mengenal sejumlah materi pelajaran tertentu ${ }^{5}$.

Ketercapaian hasil belajar siswa berkebutuhan khusus dalam kategori tinggi. Hasil ini menunjukkan tugas guru dalam pembelajaran telah menyesuaikan diri dalam membantu dan menfasilitasi pembelajaran bagi siswa ABK telah dilakukan sesuai ketentuan. Hal ini sesuai penelitian Mareza bahwa guru telah melakukan pembelajaran adaptif bagi anak berkebutuhan khusus yaitu pembelajaran yang menyesuaikan dengan kondisi siswa, artinya pembelajaran tersebut menyesuaikan dengan kondisi siswa itu sendiri, bukan siswa yang menyesuaikan dengan pembelajaran, yang tentunya penyesuaian tersebut berkaitan dengan metode strategi, materi, alat/media pembelajaran, dan lingkungan belajar6. Agar peran guru berfungsi secara maksimal, maka diperlukan tahapan bagi guru agar mampu membimbing siswa dalam kelas inklusi. Guru harus memiliki wawasan dan pemahaman akan pentingnya sikap anti diskriminatif terhadap anak berkebutuhan khusus sehingga guru dapat berperan sebagai penggerak pertama dalam membangun kesadaran siswa untuk tidak melakukan tindakan yang diskriminatif. Guru diharapkan memiliki sensitifitas yang tinggi terhadap siswa berkebutuhan khusus, terutama ketika melihat adanya diskriminasi yang berkaitan dengan perbedaan kemampuan ini. Fungsi dari tidak adanya sikap diskriminatif sangat membantu dalam proses pembelajaran sehingga semua siswa mendapatkan pembelajaran yang diberikan oleh guru secara merata dan bersamaan. Menurut Mustofa guru kelas inklusi dituntut memiliki pengetahuan terkait kurikulum dan rancangan pembelajaran sesuai dengan karakteristik anak berkebutuhan khusus tersebut ${ }^{7}$. Guru harus memahami pula karakteristik serta kelebihan dan kekurangan yang dimiliki anak berkebutuhan khusus.

Ketercapaian hasil belajar siswa berkebutuhan khusus dalam kategori tinggi menunjukkan efektifnya penerapan program pendidikan inklusi di SDN 2 Wringinanom Kab. Gresik. Hal ini sesuai penelitian Zarkasi bahwa karena

\footnotetext{
${ }^{5}$ Winkel, W. S. Psikologi Pendidikan dan Evaluasi Belajar. (Jakarta: PT. Gramedia Pustaka Utama. 2004). Hal. 22

${ }^{6}$ Mareza, L. Pengajaran Kreativitas Anak Berkebutuhan Khusus pada Pendidikan Inklusi. Jurnal Indigenous, 2016. 1(2): 99-105

${ }^{7}$ Mustofa, A. Sikap Guru Kelas terhadap Anak Berkebutuhan Khusus di Sekolah Dasar Inklusif Wilayah Kabupaten Magelang. Jurnal Widia Ortodidaktika, 2017. 6(3): 280-290
} 
baiknya pelaksanaan program pendidikan inklusif berimbas pada pencapaian hasil belajar siswa yang bisa dikatakan maksimal ${ }^{8}$.

Berdasarkan hasil analisis ini dapat disimpulkan ketercapaian hasil belajar siswa berkebutuhan khusus di SDN 2 Wringinanom Kab. Gresik secara keseluruhan diperoleh nilai rata-rata sebesar 79,28. Hasil belajar siswa berkebutuhan khusus dalam kategori tinggi. Nilai rata-rata hasil belajar siswa yang tertinggi terdapat pada kelas IV sebesar 83,34 sedangkan nilai rata-rata hasil belajar siswa yang terendah terdapat pada kelas 2 sebesar 74,37. Siswa berkebutuhan khusus di SDN 2 Wringinanom Kab. Gresik berhasil dalam mempelajari materi yang diajarkan sehingga mengalami perubahan tingkah laku. Tugas guru dalam pembelajaran telah berhasil dalam membantu dan menfasilitasi pembelajaran bagi siswa anak berkebutuhan khusus telah dilakukan sesuai ketentuan. Pelaksanaan program pendidikan inklusi di SDN 2 Wringinanom Kab. Gresik efektif sehingga hasil belajar siswa dalam kategori tinggi.

d. Data Pengaruh Ketrampilan Sosial terhadap Hasil Belajar Siswa Berkebutuhan Khusus di SDN Wringinanom Kab. Gresik

1. Deskripsi Data

Sebelum dilakukan uji hipotesis maka dilakukan uji asumsi. uji asumsi yang dilakukan pada penelitian ini yaitu uji linearitas, uji homogenitas dan uji normalitas. Uji asumsi dijelaskan sebagai berikut:

a. Uji Linearitas

Hasil uji linearitas antara variabel ketrampilan sosial terhadap hasil belajar siswa diperoleh hasil dalam tabel sebagai berikut;

Tabel IV

Hasil Uji Linearitas

\begin{tabular}{cc}
\hline Linearitas & Sig. \\
\hline Ketrampilan Sosial - Hasil & 0,276 \\
Belajar & \\
\hline
\end{tabular}

${ }^{8}$ Zarkasi, N.W. 2018. Efektivitas Program Pendidikan Inklusif terhadap Prestasi Belajar Pendidikan Agama Islam dan Budi Pekerti Siswa Inklusi di SMP Negeri 5 Surabaya. Skripsi, Program Studi Pendidikan Agama Islam, Fakultas Tarbiyah dan Keguruan, Universitas Islam Negeri Sunan Ampel Surabaya. 
Berdasarkan Tabel IV dapat diketahui bahwa hasil uji linearitas diperoleh nilai signifikansi sebesar 0,276. Nilai 0,076>0,05 sehingga dapat disimpulkan bahwa antara variabel ketrampilan sosial terhadap hasil belajar siswa terjadi hubungan yang linear.

b. Uji Homogenitas

Hasil uji homogenitas data disajikan dalam bentuk tabel sebagai berikut.

\section{Tabel V}

Hasil Uji Homogenitas

\begin{tabular}{cc}
\hline Levene Statistic & Sig. \\
\hline 1,984 & 0,170 \\
\hline
\end{tabular}

Berdasarkan Tabel V dapat diketahui bahwa hasil uji homogenis diperoleh nilai levene statistic sebesar 1,984 dengan signifikansi 0,170. Nilai signifikansi 0,170>0,05 sehingga dapat disimpulkan bahwa data yang digunakan dalam penelitian ini bersifat homogen.

c. Uji Normalitas

Uji normalitas data dilakukan menggunakan Kolmogorov-Smirnov dengan hasil disajikan dalam tabel sebagai berikut.

Tabel VI

Hasil Uji Normalitas

\begin{tabular}{cc}
\hline Kolmogorov-Smirnov Z & 0,407 \\
\hline Asymp. Sig. (2-tailed) & 0,996 \\
\hline
\end{tabular}

Berdasarkan Tabel VI dapat diketahui bahwa hasil uji Kolmogorovsmirnov diperoleh nilai 0,407 dengan nilai signifikansi sebesar 0,996. Nilai signifikansi 0,996 > 0,05 sehingga dapat disimpulkan bahwa data yang digunakan dalam penelitian ini berdistribusi normal.

Hasil uji asumsi diperoleh hasil memenuhi persyaratan untuk dilakukan uji hipotesiss. Pengujian hipotesis dilakukan menggunakan korelasi produc moment. Hasil uji hipotesis disajikan dalam tabel sebagai berikut. 
Tabel VII

Hasil Uji Korelasi

\begin{tabular}{ccc}
\hline Korelasi & R & Sig. \\
\hline $\begin{array}{c}\text { Ketrampilan sosial - Hasil } \\
\text { belajar }\end{array}$ & $-0,163$ & 0,493 \\
\hline
\end{tabular}

Hipotesis dalam penelitian ini dirumuskan sebagai berikut:

1) Hipotesis (Ha)

Terdapat pengaruh keterampilan sosial terhadap hasil belajar siswa berkebutuhan khusus di SDN 2 Wringinanom Gresik.

2) Hipotesis Nol (Ho)

Tidak ada pengaruh keterampilan sosial terhadap hasil belajar siswa berkebutuhan khusus di SDN 2 Wringinanom Gresik.

Berdasarkan Tabel VII dapat diketahui bahwa hasil uji korelasi diperoleh nilai r sebesar -0,163 dengan nilai signifikansi sebesar 0,493. Nilai signifikansi 0,493 > 0,05 sehingga hipotesis (Ha) ditolak dan hipotesis nol (Ho) diterima.

\section{d. Analisis data}

Uji hipotesis menggunakan uji korelasi diperoleh hasil yang menunjukkan bahwa tidak ada pengaruh keterampilan sosial terhadap hasil belajar siswa berkebutuhan khusus di SDN 2 Wringinanom Gresik. Hasil ini berarti hasil belajar siswa berkebutuhan khusus tidak ditentukan oleh ketrampilan sosial siswa tetapi oleh faktor yang bersifat instrinsik misalnya efikasi diri yaitu keyakinan (beliefs) tentang kemampuan seseorang untuk mengorganisasikan dan melaksanakan tindakan untuk pencapaian hasil. dengan melihat temannya yang sukses menyelesaikan tugas yang diberikan, siswa juga akan merasa yakin bahwa ia dapat berhasil mengerjakan tugas yang sama dengan temannya 9 .

Keterampilan sosial tidak berpengaruh terhadap hasil belajar siswa berkebutuhan khusus di SDN 2 Wringinanom Gresik tetapi hasil belajar siswa

9 Mukhid, A. 2009. Self-Efficacy (Perspektif Teori Kognitif Sosial dan Implikasinya terhadap Pendidikan). Jurnal Tadris, 4(1): 106-122 
dalam kategori tinggi. Hasil ini menunjukkan bahwa bukan faktor sosial yang menyebabkan hasil belajar tinggi tetapi faktor keyakinan dalam diri siswa. Menurut Mukhid perasaan efficacy yang kuat meningkatkan kecakapan seseorang dan kesejahteraan (well-being) dalam cara yang tak terbayangkan. Individu yang confident, memandang tugas-tugas yang sulit sebagai tantangan untuk dikuasai daripada sebagai ancaman untuk dihindari ${ }^{10}$. Mereka memiliki minat yang lebih kuat dan keasyikan yang mendalam pada kegiatan, menyusun tujuan yang menantang mereka, dan memelihara komitmen yang kuat serta mempertinggi dan mendukung usaha-usaha mereka dalam menghadapi kegagalan. Mereka lebih cepat memulihkan confident setelah mengalami kegagalan atau kemunduran.Keyakinan self-efficacy mempengaruhi bagaimana orang merasakan, berfikir, dan bertindak. Orang dengan selfefficacy yang tinggi, membantu menciptakan perasaan tenang dalam menghadapi tugas yang sulit.

Keterampilan sosial tidak berpengaruh terhadap hasil belajar siswa berkebutuhan khusus di SDN 2 Wringinanom Gresik tetapi hasil belajar siswa dalam kategori tinggi dikarenakan konsep diri yang positif pada siswa. Hal ini sesuai pendapat lainnya Nevid, Rathus dan Greene dalam Adicita bahwa konsep diri dapat digambarkan sebagai sistem operasi yang menjalankan komputer mental yang mempengaruhi kemampuan berpikir seseorang ${ }^{11}$. Setelah ter-install, Konsep diri akan masuk ke pikiran bawah sadar dan akan berpengaruh terhadap tingkat kesadaran seseorang pada suatu waktu. Semakin baik atau positif konsep diri seseorang maka akan semakin mudah ia mencapai keberhasilan. Sebab, dengan konsep diri yang baik, seseorang akan bersikap optimis, berani mencoba hal-hal baru, berani sukses dan berani pula gagal, penuh percaya diri, antusias, merasa diri berharga, berani menetapkan tujuan hidup, serta bersikap dan berpikir secara positif.

\section{e. Hasil Belajar}

Berdasarkan hasil uji hipotesis yang dilakukan dapat disimpulkan bahwa hasil uji korelasi diperoleh nilai $r$ sebesar $-0,163$ dengan nilai

10 Mukhid, A. 2009. Self-Efficacy (Perspektif Teori Kognitif Sosial dan Implikasinya terhadap Pendidikan). Jurnal Tadris, 4(1): 106-122

11 Adicita, Ri. 2017. Konseling Individu untuk Meningkatkan Konsep Diri Siswa Penyandang Tunarungu. Philanthrophy Journal of Psychology, 1(2): 115-12 
signifikansi sebesar 0,493 sehingga 0,493 > 0,05. Jadi hipotesis (Ha) ditolak dan hipotesis nol (Ho) diterima yaitu tidak ada pengaruh keterampilan sosial terhadap hasil belajar siswa berkebutuhan khusus di SDN 2 Wringinanom Gresik.

\section{Kesimpulan}

Hasil penelitian ini dapat disimpulkan sebagai berikut.

1. Rata-rata ketercapaian indikator secara klasikal pada siswa berkebutuhan khusus di SDN 2 Wringinanom Kab. Gresik sebesar 11,5 menunjukkan ketrampilan sosial siswa dalam kategori tinggi. Terdapat 13 siswa mencapai $\geq$ 10 indikator menunjukkan bahwa 81,25\% telah mencapai indikator ketrampilan sosial. Nilai rata-rata ketrampilan sosial siswa antar kelas cenderung sama yang menunjukkan tidak adanya perbedaan yang signifikan ketrampilan sosial siswa antar kelas.

2. Ketercapaian hasil belajar siswa secara keseluruhan diperoleh nilai rata-rata sebesar 79,28. Hasil ini berarti hasil belajar siswa di SDN 2 Wringinanom Kab. Gresik dalam kategori tinggi. Nilai rata-rata hasil belajar siswa yang tertinggi terdapat pada kelas IV 9 siswa mencapai nilai 83,34 sedangkan nilai rata-rata hasil belajar siswa yang terendah terdapat pada kelas II5 siswa mencapai hasil 74,37 .

3. Hasil uji korelasi diperoleh nilai $\mathrm{r}$ sebesar -0,163 dengan nilai signifikansi sebesar 0,493 sehingga 0,493>0,05. Jadi hipotesis (Ha) ditolak dan hipotesis nol (Ho) diterima. Tidak ada pengaruh keterampilan sosial terhadap hasil belajar siswa berkebutuhan khusus di SDN 2 Wringinanom Gresik. 
Jurnal Keislaman, Vol. 4, No. 2, September

\section{Daftar Pustaka}

A, Mustofa. Sikap Guru Kelas terhadap Anak Berkebutuhan Khusus di Sekolah Dasar Inklusif Wilayah Kabupaten Magelang. Jurnal Widia Ortodidaktika, 2017. 6(3): 280-290.

Adicita, Ri. 2017. Konseling Individu untuk Meningkatkan Konsep Diri Siswa Penyandang Tunarungu. Philanthrophy Journal of Psychology, 1(2): 115-128.

Diahwati, Rina dkk. "Keterampilan Sosial siswa Berkebutuhan Khusus diSekolahDasar Inklusi, Jurnal Pendidikan. Vol, 1. 2016.

L, Mareza. Pengajaran Kreativitas Anak Berkebutuhan Khusus pada Pendidikan Inklusi. Jurnal Indigenous, 2016. 1(2): 99-105

Mukhid, A. 2009. Self-Efficacy (Perspektif Teori Kognitif Sosial dan Implikasinya terhadap Pendidikan). Jurnal Tadris, 4(1): 106-122.

N.W, Zarkasi. Efektivitas Program Pendidikan Inklusif terhadap Prestasi Belajar Pendidikan Agama Islam dan Budi Pekerti Siswa Inklusi di SMP Negeri 5 Surabaya. Skripsi, Program Studi Pendidikan Agama Islam, Fakultas Tarbiyah dan Keguruan, Universitas Islam Negeri Sunan Ampel Surabaya.2018.

RI, Presiden. Undang-Undang Republik Indonesia, Jakarta: Repubik Indonesia, 2013.

Sugiyono, Metode Penelitian Pendidikan Kuantitatif Kualitatif dan R \& D, alfabeta bandung: 2011.

Suharmin, Tin dkk,"Pengembangan Pengukuran Keterampilan Sosial Siswa Sekolah Dasar Inklusif Berbasis Diversity Awareness". Jurnal Penelitian Ilmu Pendidikan. Vol 1. 2017.

W.S, Winkel. Psikologi Pendidikan dan Evaluasi Belajar. Jakarta: PT. Gramedia Pustaka Utama. 2004. 